\title{
A PSZICHOLÓGIAOKTATÁS SAJÁTOSSÁGAI AZ ARIZONAI ÁLLAMI EGYETEM PSZICHOLÓGIA TANSZÉKÉN
}

\author{
KÁLLAI JÁNOS \\ Janus Pannonius Tudományegyetem, Pszichológiai Intézet, \\ Személyiség-, Fejlődés és Klinikai Pszichológia Tanszék, Pécs \\ E-mail: jkallai@btk.jpte.hu
}

\begin{abstract}
A szerzö bemutatja, hogy Arizonában a pszichológusképzés a kutatólaboratóriumokra épül, s amellett érvel, hogy a pszichológusoknak a társszakmákban is végzettséget kell szerezniük - ugyanakkor hiányolja az amerikai képzésből a pszichodinamikus szemléletet.

Kulcsszavak: pszichológiaoktatás, kutatás és oktatás kapcsolata, idegtudományok
\end{abstract}

Tucson város az Arizonai Állami Egyetem központja. 800000 lakosából 65000 fó egyetemista, egyetemi állampolgár. A pszichológia tanszék a diákközponttól nem messze, a Modern Nyelvészet és a Csillagászati Intézet között található. Központi fekvése, többoldalú megközelíthetősége szimbolizálja oktatási törekvését, a társvagy a társulásra kész tanszékekkel való kollaboráció gyakorlatát. Az 1965-ben alapított négy emelet magasságú, vörös téglás önálló épületében évfolyamonként 150 hallgató tanul. Az oktatás szerkezete könnyen áttekinthető. Az oktatási követelményrendszer, a kurzus megnevezése, az előadó, az alkalmazandó ajánlott és kötelező irodalom, a vizsga módja, a kurzus részletes leírása és kifejtése mind elérhető az egyetemi számítógépes hálózaton keresztül. A hazai gyakorlathoz hasonlóan a Tanrend könyv alakban is megjelenik, de kis példányszámban, és inkább a vendégek és a tanárok ôrzik a polcaikon.

Minden egységes tantárgyat képviselő programnak van egy úgynevezett „faculty mentora”, aki a személyesen jelentkező érdeklődőket tájékoztatja az adott programmal kapcsolatos kutatási lehetőségeket, szakmai karrierformákat illetően, valamint a kurzusbővítés lehetőségeiről, emellett tanácsot ad a kiegészítő tárgyak felvételéről. 
Az oktatás struktúrája nagyon szervezett, és ennek a szervezettségnek a kiszolgálása meghatározza a végzett oktatási munkát. Maga az oktatási közeg néha olyan benyomást tesz, mintha ha nem az oktató, hanem az egyetemi struktúra végezné az oktatást. E területen nincs pardon: az oktatónak szolgálnia kell. Autonómiáját, függetlenségét más területen élheti ki. Ennek a nyomai világosan láthatók. A pszichológia tanszéken több mint 20 kutató laboratórium müködik. Az oktatás fenntartása, az infrastruktúra fejlesztése a 4 adminisztrátorral, egy gazdasági és egy általános igazgatási feladatokat ellátó és két technikus szakemberrel dolgozó igazgatási iroda feladata. A fakultásoknak az igazgatás által biztosított pénzügyi és adminisztrációs lehetőségei szűkösek. Az igazgatás következetes, racionális. Az igazi szakmai munka központját az önálló kutatólaboratóriumok jelentik. Önállóságuk alapja az, hogy saját kutatási pályázatból finanszírozzák tevékenységüket. A kutatók laboratóriumai egyben a gyakorlati foglalkozások színterei is. Sok hallgatóval dolgoznak, az esetek többségében a laboratórium profiljába vágó kutatások bonyolításában vagy próbavizsgálatok elkészítésében vesznek részt. E tekintetben a kutatásvezetők szerencsések. Az alsóbb éves hallgatók is magas szintű computerismerettel, metodikai felkészültséggel, statisztikai megalapozottságú kutatásmódszertani ismertekkel lépnek be a graduális képzésbe, és így aktív részesei a laboratóriumokban zajló kutatásoknak. A laboratóriumok közül néhány felsorolásként és bemutatásként. Center of Consciousness Study, Anxiety Research Group, Complementary and Alternative Medicine Research Group, Environmental Perception, Event Related Potential, Family Research, Memory, Cognition and Ages, The Sleep Research, Speech Perception, Visual Perception, Perceptual Learning Laboratóriumok és így tovább. A laboratóriumok közül, a Családkutató Laboratórium, valamint a kutató munkám színhelyét képező Szorongáskutató Laboratórium tevékenységét mutatom be részletesebben.

Az Amerikai Egyesült Államok kormányának hosszú távon kiemelt programja a nehéz anyagi és személyes körülmények között élő családok élethelyzetének segítése, megfelelő beavatkozási stratégiákat előkészítő kutatások ösztönzése. A kutatócsoport az Arizonában nagy számban élő különböző nemzetiségek, elsősorban a spanyol anyanyelvủ bevándorolt mexikói családokban tapasztalt nehézségek okának felderítésén fáradozik. A vizsgálatok központjában az anya viselkedésének, a családban vállalt megtartó szerepének a tanulmányozása áll. Az apákat nehezebb bevonni a vizsgálatokba, így vonatkozásukban indirektebb információkkal dolgoznak. A női mivoltnak, az anya a gyermekek fejlődésére és egészségi állapotának megőrzésére gyakorolt hatását vizsgálják, elsősorban interjú és egészségügyi statisztikai vizsgálati eszközökkel.

A Szorongáskutató Laboratórium munkája a tanszék oktatási és kutatási koncepciója modelljének is tekinthető. Graduális hallgatók folyamatosan részt vesznek a kutatások előkészítésében. Néhányan belső pályázati keretből anyagilag is meg tudják alapozni a munkájukat. A szorongás autobiográfiai emlékezetre, téri tájékozódásra gyakorolt hatásait vizsgálják. A témavezető idegtudományokban jártas agykutató, a laboratórium vezetője klinikai pszichológiai végzettségű kutató. A csoport szorosan együttműködik a klinikai pszichológiai gyakorlattal, biokémikusokkal és percepciókutatókkal. Klinikai kapcsolataik révén tudják bonyolítani a 
vizsgálataikat és realizálni az eredményeket. A korszerű idegtudományos gondolkodás teljes mértékben érvényesül a laboratórium munkájában. Elsősorban a poszttraumatikus stressz betegség, valamint más szorongásos betegségek vonatkozásában zajlanak kutatások, fMRI, computer által létrehozott virtuális tájékozódási feladatok és reális élettérben végzett tájékozódás módszerekkel.

A laboratóriumok munkája általában nem függ közvetlenül az oktatástól. A szerteágazó, a szakma határait némileg átlépő kutatási és oktatási kapcsolatrendszer képezi az egyik legintenzívebb szakmai fejlődési potenciált. A tudományok határainak közeledése a kognitív tudományokhoz hasonlóan az idegtudományok területére is vonatkozik. A különböző területeken és metodikával dolgozó szakemberek együttműködésében gyökerezik a fejlődés. Ugyanúgy, ahogy ez a klinikumban vagy a mentálhigiénés tevékenységben, a család- és ifjúságvédelemben és sorolhatnám még, megfigyelhető. Ez a sokszínűség az oktatásban is megjelenik. A pszichológia tanszék vezetője és a mentorok is kifejezetten támogatják, ösztönzik a második diploma megszerzését. Elsősorban pedagógia, biológia, nyelvészet, szociológia, politikai tudományok, jogtudomány, de más területeken is. Másrészt sok nyelvész, pszichiáter, gyógypedagógus, neurólogus vesz rész az oktatásban. Az arizonai egyetemen - hasonlóan az amerikai egyetemek többségéhez - félállású oktatók töltik be az állások 40\%-át. Ennek okait Magyarországról is jól ismerjük. Egyrészt óriási előnyei vannak, nemcsak az egyetemi gazdasági hivatal szempontjából, mert lényegesen olcsóbb így a tanszékek fenntartása, de a félállású oktató a gyakorlatból a praxis oldaláról állandó friss szemléletet hoz, példákkal gazdagítja az oktatást és lehetőségekkel a kutatást. A hallgatók keresik is ezeket a lehetőségeket. A másik következmény azonban az időprés. Az oktatók nehezen elérhetők, jobbára csak a félfogadási időben, a kiírtak szerint tartózkodnak ott, akkor sem biztos, és a személyes tutori, iskolateremtő tanítványi és munkatársi kapcsolat sajnálatos módon háttérbe szorul, még akkor is, ha az egyetemi struktúra igyekszik támogatni a hallgató és az oktató szabad találkozását.

Az egyetemi pszichológia oktatás céljáról, módszereiről, a prioritásokról, más intézményekhez és a gyakorlati képzéshez való kapcsolódás formájáról állandó vita folyik mind a személyes beszélgetések, mind a szakmai sajtó színterén Arizonában is (BELER 1998, valamint Robins, GOSLING, CRAIK, 1999 vitája az American Psychologist hasábjain). Az arizonai pszichológiai tanszék doktori programja föleg klinikai orientáltságú - ennek megfelelő a graduális képzés is. Ebből adódóan a klinikai pszichológiával kapcsolatos helyi véleményeket és adatokat tudom leginkább közvetíteni. A klinikai pszichológia tekintetében a végzett kollégák közül sokan jelentkeznek az államok különböző területeiről az Arizonai Pszichológiai Tanszék által működtetett PhD-iskolába. A felvettek 68\%-a hölgy, 25\% valamilyen minoritás képviselője; a jelentkezők átlagéletkora 28-29 év. A doktori iskola célja a tudományos alapokon nyugvó praxis elsajátíttatása. Ennek ellenére a 4 éves doktori iskola után többen választják az egyetemi katedrát, mint a gyakorlati klinikai pszichológiai munkát. A pszichológiai doktori iskola szorosan együttműködik a kognitív tudomány és az idegtudomány programokkal, ami annak ellenére, hogy a hallgatók különböző témákban folytatott kutatását és praxis szerzését kifejezetten támogatják, nagymértékben meghatározza a hallgatók orientációját, a disz- 
szertáció megvédése utáni karrierjét. A graduális képzést befejező, valamint a doktori iskolát lezáró kollégák közül általában $20 \%$ oktatásban, $20 \%$ kórházakban, klinikákon, 15\% független magánpraxisban helyezkedik el, 10\% management és fejlesztő tréningekkel foglalkozik, 22\% mentálhigiénés közösségekkel foglalkozó pszichológiai területen dolgozik, mások tanácsadókban, sport és egyéb területeken.

Hasonlóan a magyar szakmai közeghez - mint a fentiekben már utaltam rá folyamatos és intenzív vita zajlik a képzés fő vonaláról. Kiemelek ezek közül néhány gondolatot. A rohamos technikalizáció hatására drámai változások mennek végbe az oktatásban. Az internet által biztosított „cyberspace” mesterséges világa teljes oktatási programokat tesz hozzáférhetővé, tesztanyaggal, oktatási mellékletekkel, kontroll módszerekkel (mentális státus felmérése, pszichológiai teszt felvétele, tanácsadás és pszichológiai beavatkozás, interjútechnikai ismeretek, anatómia, neurológia, computeres egészségügyi tanácsadás, önkontroll és lelkiegészségépítő computeres gyakorlatok interaktív CD-ROM megjelenítésben a mostani idők fejlődő gyakorlatát jelentik). Ezek a technikai vívmányok jelentősen segítik az elméleti tárgyak elsajátítását, de a kapcsolatorientált szemlélet, a helper attitűd levezetésére nem adnak lehetőséget, eltorzítják a kapcsolatra irányuló érzelmeket. E megközelítésben a hatékony tudományos elvekre épített oktatás menetében a kapcsolatorientált szemléletben oktatott pszichológiai gyakorlat a pszichológia „zöld” mozgalmaként háttérbe szorul és elvérzik a tudományos fegyverekkel folytatott csatában. A mentálhigiénés képzésben és gyakorlatban elkötelezett szakemberek álláspontja szerint a pszichológia gyakorlatának csoportokkal, egyénekkel hatékonyan bánni tudó szakemberekre van szükség, mindegy, hogy szociális munkásnak nevezik őket vagy pszichológusnak, lényeg, hogy sokoldalú emberi ismerete és gyakorlati jártassága legyen. Egyes vélemények szerint az ilyen szakemberek képzésére az állami szervezetek is intenzívebb támogatást adnak, mert szükség van és lesz is rájuk. Az Amerikai Egyesült Államok lakosságának csaknem a negyedét a kisebbségi kultúrát képviselő különböző nemzetiségű és kultúrájú emberek alkotják. Az ebből származó problémák egyesek szerint várhatóan nagy kihívást jelentenek a pszichológus szakma számára. A mentálhigiénében elkötelezett oktatók és ilyen gyakorlatot folytatók úgy vélik, hogy a pszichológia eredeti tartalma szerint segítő hivatás, és erre kell a hallgatókat felkészíteni. Legyen gyakorlatuk a kapcsolat megteremtésében, vezetésében, tudjanak csoportokkal bánni és individuális hatásokat kifejteni. Tehát nagy szükség van a szociálisan, politikailag, oktatás tekintetében képzett, kultúrantropológiában is jártas, a társszakmákkal együttműködni kész pszichológusokra. A mentálhigiénében dolgozó szakemberek, ebből adódóan lényegében „haza várják” az eltévedt pszichológus kollégákat, akik a tudomány és a gyakorlat jelentős kettős terhe alatt próbálnak érvényesülni. Sokak szerint ezeket a véleményeket a gyakorlati ambíció, a közösségteremtés igénye, a segítő attitűd kifejtése hajtja. Úgy gondolják, hogy ezek a vélemények nem artikulálják a pszichológia szakma történetileg megalapozott profilját, a politika mezsgyéjére tévednek, és a szakmai autonómiát, a szakma fejlődési potenciálját alábecsülik. A „pszicho-lógia” megnevezésben csupán az első tagra koncentrálnak és feladják a második tag értelmezését, a pszichológia kifejezésben 
és a pszichológia gyakorlatában lévő feszültség feloldását vagy képviseletét. Más véleményekben elhangzik, hogy attól, hogy valaki ért a tudományhoz, nem szükségszerüen hiányzik a gyakorlati érzeke. Ezeket a vitákat azonban tudományos igényesség általában nem jellemzi. Az ilyen jellegű álláspontok sem az egyik, sem a másik oldalon empirikus bizonyítékokat nem sorakoztatnak fel.

Mások statisztikákra épített szakmai fejlődési trendeket hangsúlyoznak, melyben nagy szerepet kap a tudományos publicitás. E trendek alapján úgy látják, hogy a pszichológia a második kognitív forradalom kibontakozásának időszakában van, s ugyanakkor hangsúlyozzák a szakma tudományos elsajátításának fontosságát. Kiemelik a kettős diploma megszerzésének elkerülhetetlenségét és a más szakmákkal, tudományágakkal való együttmúködésre buzdítanak. A kognitív tudományt állítják mintául, ahol a matematika, informatika, nyelvészet, filozófia, pszichológia választ közös kutatási területet. Hasonló elvek mutatkoznak az idegtudományok területén is: pszichiátria, percepció, emlékezetkutatás, neurológiai, idegsebészeti kutatások összekapcsolódását látjuk. Ezekkel az empirikusnak látszó, publicitásra építő véleményekkel kapcsolatban felvetik, hogy a tudományos publicitás sem tudományos minőséget, sem hasznosságot, sem gyakorlati praktikus effektivitás nem tartalmaz, és ezek alapján különböző iskolák vagy gyakorlati orientációk fejlődési trendjét nem lehet megítélni. A fenti tényekkel és vitákkal a graduális képzés irányítói és a doktori iskolák akkreditációjában részt vevő szakemberek szembesülnek. A két álláspont között elég széles a mozgástér. Az arizonai szakmai élet irányítói a tudomány és praxis együttműködését és a társszakmákkal való kollaborációt hangsúlyozzák. A speciális kérdések megoldását a társaságokra, egyesületekre bízzák.

Az Egyesült Államoknak nincs egységes oktatási szisztémája, minden állam maga határozza meg az oktatási profilt. A többi a hallgató dolga, eldönteni, hogy melyik graduális képzést, melyik doktori iskolát vagy továbbképzési formát választja. Az arizonai egyetem doktori iskolája kutatás- és praxisorientált egyben, de aki a praxis oldalán dinamikus iskolában szeretné képezni magát, az ne az arizonai egyetemet válassza. Az európai szem számára szokatlan, hogy a projektív tesztek gyakorlati oktatása, elméleti alapjainak részletes ismertetése hiányzik a graduális és a PhD-programból. Helyüket a legkülönbözőbb kérdőíves metodikák, listák és a neuropszichologiai vizsgálatok és a teljesítménytesztek töltik ki.

Kétségtelen, hogy az idegtudományok, a kognitív tudomány tekintetében óriási oktatási és kutatási produktum áll az arizonai pszichológiai tanszék háta mögött. Laboratóriumai a világ élvonalába tartozó új eredményeket szolgáltatnak. Mindemellett azonban szokatlan a kapcsolatorientált dinamikus szemlélet viszonylagos visszavonultsága.

Az oktatás infrastuktúrája megbízhatóan, következetesen működik. Amerikai vélemények szerint a világ legjobb graduális képzési színhelyei az ehhez hasonló intézmények. Van mit tanulnunk tőlük. Nem tudom, mit szólnának az arizonai kollégák, ha közvetlenül megismernék a magyar oktatási gyakorlatot. Néhány vonatkozásban talán ugyanezt mondanák. 


\title{
IRODALOM
}

Beler, C. D. (1998) Graduate education in clinical psychology, American Psychologist, Vol 53., No 4., 456-467.

Robins, R. W., Gosling, S. D., Craik, K. H. (1999) An empirical analysis of trends in psychology, American Psychologist, Vol. 54., No. 2., 117-128.

\section{THE TEACHING OF PSYCHOLOGY ON THE ARIZONA UNIVERSITY}

\author{
KÁLLAI, JÁNOS
}

In Arizona, education in psychology is based on research labs. The author argues for second degrees in related fields. He points out the lack of psychodynamic points in American training.

Key words: $\quad$ teaching of psychology, research and teaching, neuroscience 